\title{
Influence of different methods of bacterial nucleic acid isolation on sensitivity of the PCR assay
}

\section{Wpływ różnych sposobów izolacji kwasów nukleinowych z bakterii na czułość testu PCR}

\author{
Włodzimierz Przewodowski*, Chołuj Joanna, Przewodowska Agnieszka
}

\begin{abstract}
Summary
Isolation of nucleic acids of different plant pathogens is one of the most important stages, which have influence on the correct molecular diagnosis of these pathogens. This study investigated the suitability of two different DNA isolation techniques used in the diagnosis of Clavibacter michiganensis ssp. sepedonicus $(\mathrm{Cms})$ - quarantine bacteria responsible for potato ring rot. The quality of the isolated DNA and the sensitivity of the two methods were assessed by spectrophotometric analysis, respectively/and the sensitivity of electrophoretic DNA PCR (polymerase chain reaction) assay. Two methods of DNA extraction were compared. The first of them with CTAB (cetyltrimethylammonium bromie) method allowed to remove the components of plant tissues and while destructing membranes released nucleic acids from bacterial cells (method 1). In the second method extraction of genomic DNA was done in the presence of high concentrations of salt, which involved the selective precipitation of nucleic acids (method 2). In addition to the efficiency of the compared extraction methods the impact of bacterial slime and buffer components on the quality of the obtained DNA were also assessed. It has been shown that the best quality of DNA and PCR sensitivity was obtained using the CTAB method. The high mucoid level of tested strains only marginally reduced the detection of bacteria Cms in PCR assay.
\end{abstract}

Key words: Clavibacter michiganensis ssp. sepedonicus; DNA isolation; PCR; CTAB

\section{Streszczenie}

Izolacja kwasów nukleinowych patogenów roślin jest jednym z najważniejszych etapów warunkujących prawidłową diagnostykę molekularną tych patogenów. W pracy badano przydatność różnych technik izolacji DNA kwarantannowych bakterii Clavibacter michiganensis ssp. sepedonicus $(\mathrm{Cms})$ - sprawcy bakteriozy pierścieniowej ziemniaka, stosowanych w diagnostyce bakteryjnych patogenów ziemniaka. Jakość wyizolowanego DNA oraz czułość obu metod oceniano na podstawie odpowiednio analizy spektrofotometrycznej/elektroforetycznej DNA oraz czułości testu PCR (polymerase chain reaction - łańcuchowej reakcji polimerazy). Porównywano dwie różne metody izolacji DNA. Pierwsza z nich - metoda z wykorzystaniem CTAB (cetyltrimethylammonium bromie bromek cetylotrimetyloamoniowy) umożliwia usunięcie komponentów tkanek roślinnych oraz destrukcję błon i uwolnienie kwasów nukleinowych z komórek bakterii (metoda 1). W drugiej z porównywanych metod ekstrakcję genomowego DNA przeprowadzano w obecności wysokiego stężenia soli powodującego selektywne wytrącanie kwasów nukleinowych (metoda 2). Oprócz efektywności metod ekstrakcji oceniano również wpływ śluzów bakteryjnych oraz komponentów buforów na jakość uzyskanych preparatów DNA. Wykazano, iż najlepszą jakość DNA i czułość testu PCR uzyskano stosując metodę CTAB, a wysoka mukoidalność badanych szczepów jedynie w nieznacznym stopniu obniżyła wykrywalność bakterii Cms testem PCR.

Słowa kluczowe: Clavibacter michiganensis ssp. sepedonicus; izolacja DNA; PCR; CTAB

Instytut Hodowli i Aklimatyzacji Roślin - Państwowy Instytut Badawczy

Zakład Nasiennictwa i Ochrony Ziemniaka

Bonin 3, 76-009 Bonin

*corresponding author: w.przewodowski@ihar.edu.pl 


\section{Wstęp / Introduction}

Izolacja kwasów nukleinowych (DNA/RNA) patogenów roślin jest ważnym początkowym etapem wielu procedur diagnostycznych stosowanych w biologii molekularnej, warunkującym poprawność identyfikacji tych patogenów. Jednym z najważniejszych elementów pozwalających na uzyskanie wysokiej czułości testu molekularnego jest odpowiednia jakość wyizolowanego materiału genetycznego oraz możliwość usunięcia substancji, które mogłyby niekorzystnie wpływać na wynik reakcji PCR (polymerase chain re action - łańcuchowej reakcji polimerazy). Oba te parametry w znacznym stopniu uzależnione są od sposobu izolacji kwasów nukleinowych (Mak i Ho 1992). W przypadku izolacji DNA bakteryjnego z prób roślinnych, a szczególnie bulw ziemniaka zawierających znaczną ilość komponentów aktywnych enzymatycznie, efektywność procesu izolacji oraz czystość otrzymanych preparatów jest zależna od zastosowanej metody ekstrakcji kwasów nukleinowych (Van Bechoven i wsp. 2002). Dodatkowo obecność śluzów zawierających egzopolisacharydy, którymi pokryte są komórki bakterii Clavibacter michiganensis ssp. sepedonicus (Cms) oraz inhibitorów reakcji PCR pochodzenia roślinnego może znacząco obniżyć czułość testów molekularnych.

Jedną z częściej stosowanych metod izolacji DNA $\mathrm{z}$ tkanek roślinnych jest technika opracowana przez Doylle i Doylle (1987), z użyciem jonowego detergentu CTAB (cetyltrimethylammonium bromie - bromek cetylotrimetyloamoniowy) oraz mieszaniny chloroformu i alkoholu izoamylowego. W metodzie tej na skutek zastosowanych odczynników dochodzi do rozerwania błon komórkowych, a następnie oddzielenia kwasów nukleinowych znajdujących się w fazie wodnej od pozostałych komponentów zawartych w fazie organicznej. Metoda jest szczególnie polecana do analizy próbek bogatych w polisacharydy i zanieczyszczenia polifenolowe. Alternatywna metoda ekstrakcji DNA opracowana przez Ewardsa i wsp. (1991) opiera się na wykorzystaniu innego detergentu o nazwie dodecylosiarczan sodu (SDS), proteinazy K i wysokiego stężenia soli $\mathrm{NaCl}$. Jest to metoda prostsza w wykonaniu i tańsza w porównaniu z metodą CTAB. W prezentowanej pracy porównano wydajność obu metod izolacji DNA, a otrzymane preparaty kwasów nukleinowych oceniano pod względem czystości i przydatności do testu PCR.

DNA izolowano z komórek gram dodatnich bakterii Cms, sprawcy bakteriozy pierścieniowej ziemniaka. Ze względu na specyfikę tego patogenu, obecność egzopolisacharydów bakteryjnych otaczających bakterie $\mathrm{Cms}$, a także obecność wielu substancji towarzyszących w ekstraktach z bulw ziemniaka, efektywna izolacja DNA może być utrudniona. Ponadto obecność inhibitorów reakcji PCR może dawać wyniki fałszywie ujemne w testach molekularnych.

\section{Materiały i metody / Materials and methods}

DNA izolowano z komórek bakteryjnych dwóch skrajnie zróżnicowanych mukoidalnie szczepów Cms przygotowanych $\mathrm{w}$ postaci świeżo sporządzonych 48-godzinnych zawiesin bakteryjnych. Czułość metod oceniano sporządzając zawiesiny bakterii o stężeniu od 100 do $10 \mathrm{mln}$ jednostek tworzących kolonie w mililitrze (jtk/ml) w różnych mediach, takich jak: sterylna woda, ekstrakt roślinny z bulw ziemniaka oraz bufor fosforanowy. Ekstrakt roślinny przygotowano $\mathrm{z}$ bulw odmiany Baszta umytych i osuszonych papierowym ręcznikiem, które przecierano wraz ze skórką na plastikowej tarce. Ciecz znad osadu miąższu zlewano i przesączano przez sterylną gazę. Tak uzyskany ekstrakt porcjowano do $2 \mathrm{ml}$ probówek Eppendorff i dodawano bakterie Cms uzyskując oczekiwane stężenie komórek w objętości $1 \mathrm{ml}$.

Do badań stosowano dwie metody izolacji DNA. $\mathrm{W}$ pierwszej metodzie $\mathrm{z}$ wykorzystaniem odczynnika CTAB, przygotowane zawiesiny wirowano $10 \mathrm{~min}$ $10000 \times \mathrm{g}$, usunięto supernatant pozostawiając $100 \mu \mathrm{l}$ cieczy nad osadem. Osad rozpuszczono w buforze $400 \mu \mathrm{l}$ $1 \times$ PBS (bufor fosforanowy) z 0,2\% BSA (albumina wołowa), dodano $800 \mu \mathrm{l}$ podgrzanego do $60^{\circ} \mathrm{C}$ buforu CTAB z $0,2 \%$ Me, a następnie całość intensywnie mieszano i inkubowano $20 \mathrm{~min} \mathrm{w} 60^{\circ} \mathrm{C} \mathrm{w}$ łaźni wodnej od czasu do czasu mieszając. Dodano $600 \mu \mathrm{l}$ mieszaniny chloroform:alkohol izoamylowy (24:1), mieszano energicznie i wirowano $10000 \times \mathrm{g}$ przez $10 \mathrm{~min}$. Supernatant przeniesiono do nowej probówki i dodano równoważną objętość zimnego izopropanolu. Całość dobrze wymieszano $\mathrm{i}$ umieszczono na około $30 \mathrm{~min} \mathrm{w}-20^{\circ} \mathrm{C}$, a potem wirowano $10000 \times \mathrm{g}$ przez $10 \mathrm{~min}$. Uzyskany osad przepłukano $500 \mu$ l objętością $80 \%$ EtOH i po usunięciu alkoholu, suszono $\mathrm{w}$ termobloku $\mathrm{w}$ temperaturze $55^{\circ} \mathrm{C}$. DNA rozcieńczano w $50 \mu 1$ sterylnej $\mathrm{H}_{2} \mathrm{O}$.

$\mathrm{W}$ drugiej $\mathrm{z}$ metod, wysokosolnej, przygotowane zawiesiny zwirowano wstępnie, podobnie jak w metodzie CTAB, odebrano $800 \mu \mathrm{l}$ z każdej probówki, pozostawiając docelowo $200 \mu \mathrm{l}$ zawiesiny ze zwirowanym osadem. Dodano $200 \mu \mathrm{l} 200 \mathrm{mM}$ Tris-Cl pH 8,0 (zawierającego $0,8 \mathrm{M} \mathrm{NaCl}$ i $4 \mathrm{mM}$ EDTA). Do każdej z prób dodano $40 \mu \mathrm{l} 10 \%$ SDS-u oraz $8 \mu \mathrm{l}$ proteinazy $\mathrm{K}(0,4 \mathrm{mg} / \mathrm{ml})$ i całość inkubowano $\mathrm{w}$ temperaturze $62^{\circ} \mathrm{C}$ całą noc we wytrząsarce laboratoryjnej. Dodano $300 \mu \mathrm{l} 6 \mathrm{M} \mathrm{NaCl}$ (do stężenia $5 \mathrm{M}$ ). Próby intensywnie mieszano przez $30 \mathrm{~s}$ przy maksymalnych obrotach, następnie wirowano $30 \mathrm{~min}$ $10000 \times$ g. Supernatant przeniesiono do nowej probówki i dodano około $800 \mu \mathrm{l}$ zimnego izopropanolu. Całość dobrze wymieszano przez odwracanie probówek. Próby inkubowano przez $1 \mathrm{~h} \mathrm{w}-20^{\circ} \mathrm{C}$, a następnie wirowano $20 \min \mathrm{w} 10000 \times \mathrm{g}$. Osad przemyto (pozostawiono na $5 \mathrm{~min}) 200 \mu \mathrm{l} 70 \%$ etanolu. Po ostrożnym usunięciu etanolu osad suszono (około $5 \mathrm{~min}$ ) w temperaturze $55^{\circ} \mathrm{C}$ w termobloku przy włączonym wyciągu. DNA rozcieńczano w $50 \mu$ l dejonizowanej i sterylnej wody.

Ilość otrzymanego DNA oznaczono za pomocą spektrofotometru mikropłytkowego Epoch (BioTek) na podstawie stosunku absorbancji A260/A280 (tab. 3). Preparaty DNA rozdzielano w $1,5 \%$ żelu agarozowym stosując napięcie $140 \mathrm{~V}$ przez 40 minut (rys. 1). Test PCR prowadzono według warunków opisanych przez Pastrik i Maiss (2000). Jako kontrolę negatywną do testu PCR stosowano media bez zawiesin Cms. DNA ze wszystkich prób izolowano trzykrotnie, każdą próbę $\mathrm{w}$ dwóch powtórzeniach. 
Tabela 1. Czułość testu PCR dla niskomukoidalnego szczepu bakterii Clavibacter michiganensis subsp. sepedonicus (Cms)

Table 1. The sensitivity of the PCR assay for low mucous strain of Clavibacter michiganensis subsp. sepedonicus (Cms) bacteria

\begin{tabular}{l|c|c|c|c|c|c|c|c|c|c|c|c|c|c|c|c|c|c|c}
\hline $\begin{array}{c}\text { Szczep niskomukoidalny } \\
\text { Low mucous strain }\end{array}$ & \multicolumn{3}{|c|}{ Sok z bulw - Tuber extracts } & \multicolumn{7}{c|}{$1 \times$ PBS } & \multicolumn{7}{c}{$\mathrm{H}_{2} \mathrm{O}$} \\
\hline Cms [jtk/ml] & $10^{7}$ & $10^{6}$ & $10^{5}$ & $10^{4}$ & $10^{3}$ & $10^{2}$ & $10^{7}$ & $10^{6}$ & $10^{5}$ & $10^{4}$ & $10^{3}$ & $10^{2}$ & $10^{7}$ & $10^{6}$ & $10^{5}$ & $10^{4}$ & $10^{3}$ & $10^{2}$ \\
\hline Metoda 1-Method 1 & + & + & + & + & + & + & + & + & + & + & - & - & + & + & + & + & + & - \\
\hline Metoda 2- Method 2 & + & + & + & + & + & + & + & + & + & + & + & - & + & + & + & + & - & - \\
\hline
\end{tabular}

PBS - bufor fosforanowy - phosphate buffer

Tabela 2. Czułość testu PCR dla szczepu mukoidalnego bakterii Clavibacter michiganensis subsp. sepedonicus (Cms)

Table 2. The sensitivity of the PCR assay for mucous strain of Clavibacter michiganensis subsp. sepedonicus (Cms) bacteria

\begin{tabular}{l|c|c|c|c|c|c|c|c|c|c|c|c|c|c|c|c|c|c}
\hline $\begin{array}{c}\text { Szczep mukoidalny } \\
\text { Mucous strain }\end{array}$ & \multicolumn{3}{|c|}{ Sok z bulw - Tuber extracts } & \multicolumn{1}{c}{$1 \times$ PBS } & \multicolumn{7}{c}{$\mathrm{H}_{2} \mathrm{O}$} \\
\hline Cms $[\mathrm{jtk} / \mathrm{ml}]$ & $10^{7}$ & $10^{6}$ & $10^{5}$ & $10^{4}$ & $10^{3}$ & $10^{2}$ & $10^{7}$ & $10^{6}$ & $10^{5}$ & $10^{4}$ & $10^{3}$ & $10^{2}$ & $10^{7}$ & $10^{6}$ & $10^{5}$ & $10^{4}$ & $10^{3}$ & $10^{2}$ \\
\hline Metoda 1 - Method 1 & + & + & + & + & + & - & + & + & + & + & + & - & + & + & + & + & + & - \\
\hline Metoda 2 - Method 2 & + & + & + & + & + & - & + & + & + & + & + & - & + & + & + & + & - & - \\
\hline
\end{tabular}

PBS - bufor fosforanowy - phosphate buffer

Tabela 3. Porównanie ilości DNA wyizolowanego z mukoidalnego (M) i niskomukoidalnego szczepu bakterii Clavibacter michiganensis subsp. sepedonicus (Cms)

Table 3. Comparison of the amounts of DNA isolated from mucous (M) and low mucous strain of Clavibacter michiganensis subsp. sepedonicus (Cms) bacteria

\begin{tabular}{l|c|c}
\hline \multicolumn{1}{c|}{$\begin{array}{c}\text { Materiał do izolacji DNA } \\
\text { Material for DNA isolation }\end{array}$} & $\begin{array}{c}\text { Metoda } 1 \\
\text { Method 1 }\end{array}$ & $\begin{array}{c}\text { Metoda } 2 \\
\text { Method 2 }\end{array}$ \\
\cline { 2 - 3 } & $\begin{array}{c}\text { ilość wyizolowanego DNA } \\
\text { amount of isolated DNA } \\
\text { [ug/ul] }\end{array}$ \\
\hline $\begin{array}{l}\text { Szczep niskomukoidalny bakterii } C m s \text { w soku ziemniaka } \\
\text { Low mucous strain of } C m s \text { bacteria in tuber extract }\end{array}$ & $0,354 \pm 0,025$ & $0,089 \pm 0,012$ \\
\hline $\begin{array}{l}\text { Szczep mukoidalny bakterii } C m s \text { w soku ziemniaka } \\
\text { Mucous strain of } C m s \text { bacteria in tuber extract }\end{array}$ & $0,404 \pm 0,076$ & $0,118 \pm 0,022$ \\
\hline $\begin{array}{l}\text { Szczep niskomukoidalny bakterii } C m s \text { w } 1 \times \text { PBS } \\
\text { Low mucous strain of } C m s \text { bacteria in } 1 \times \text { PBS }\end{array}$ & $0,023 \pm 0,003$ & $0,006 \pm 0,001$ \\
\hline $\begin{array}{l}\text { Szczep mukoidalny bakterii } C m s \text { w } 1 \times \text { PBS } \\
\text { Mucous strain of } C m s \text { bacteria in } 1 \times \text { PBS }\end{array}$ & $0,029 \pm 0,009$ & $0,012 \pm 0,004$ \\
\hline $\begin{array}{l}\text { Szczep niskomukoidalny bakterii } C m s \text { w wodzie } \\
\text { Low mucous strain of } C m s \text { bacteria in water }\end{array}$ & $0,030 \pm 0,005$ & $0,020 \pm 0,003$ \\
\hline $\begin{array}{l}\text { Szczep mukoidalny bakterii } C m s \text { w wodzie } \\
\text { Mucous strain of } C m s \text { bacteria in water }\end{array}$ & $0,026 \pm 0,007$ & $0,064 \pm 0,006$ \\
\hline
\end{tabular}

PBS - bufor fosforanowy - phosphate buffer

\section{Wyniki i dyskusja / Results and discussion}

Szybkie, czułe i specyficzne metody identyfikacji patogenów bakteryjnych są szczególnie ważne w przypadku patogenów powodujących groźne, kwarantannowe choroby, skutkujące wysokimi stratami ekonomicznymi. Wiarygodność testów molekularnych, w których DNA identyfikowanego patogenu jest amplifikowane w reakcji PCR, zależy w znacznym stopniu od jakości matrycy DNA wyizolowanej z badanej próby. Ekstrakty roślinne bogate w polisacharydy, komponenty fenolowe oraz inne meta- bolity wtórne mogą hamować reakcję PCR lub łączyć się z DNA po lizie komórek (John 1992). Opracowano wiele metod izolacji kwasów nukleinowych pozwalających wyeliminować niekorzystny wpływ komponentów roślinnych na wydajność tego procesu oraz wynik testu diagnostycznego (Doyle i Doyle 1987, 1990; Sharma i wsp. 2002). Jedną $\mathrm{z}$ częściej stosowanych metod $w$ izolacji DNA $\mathrm{z}$ tkanek roślinnych jest metoda $\mathrm{z}$ użyciem kationowego detergentu (CTAB). Technika ta została pierwotnie opracowana przez Doyle i Doyle (1987), a następnie wielokrotnie modyfikowana i zaadaptowana do izolacji DNA 


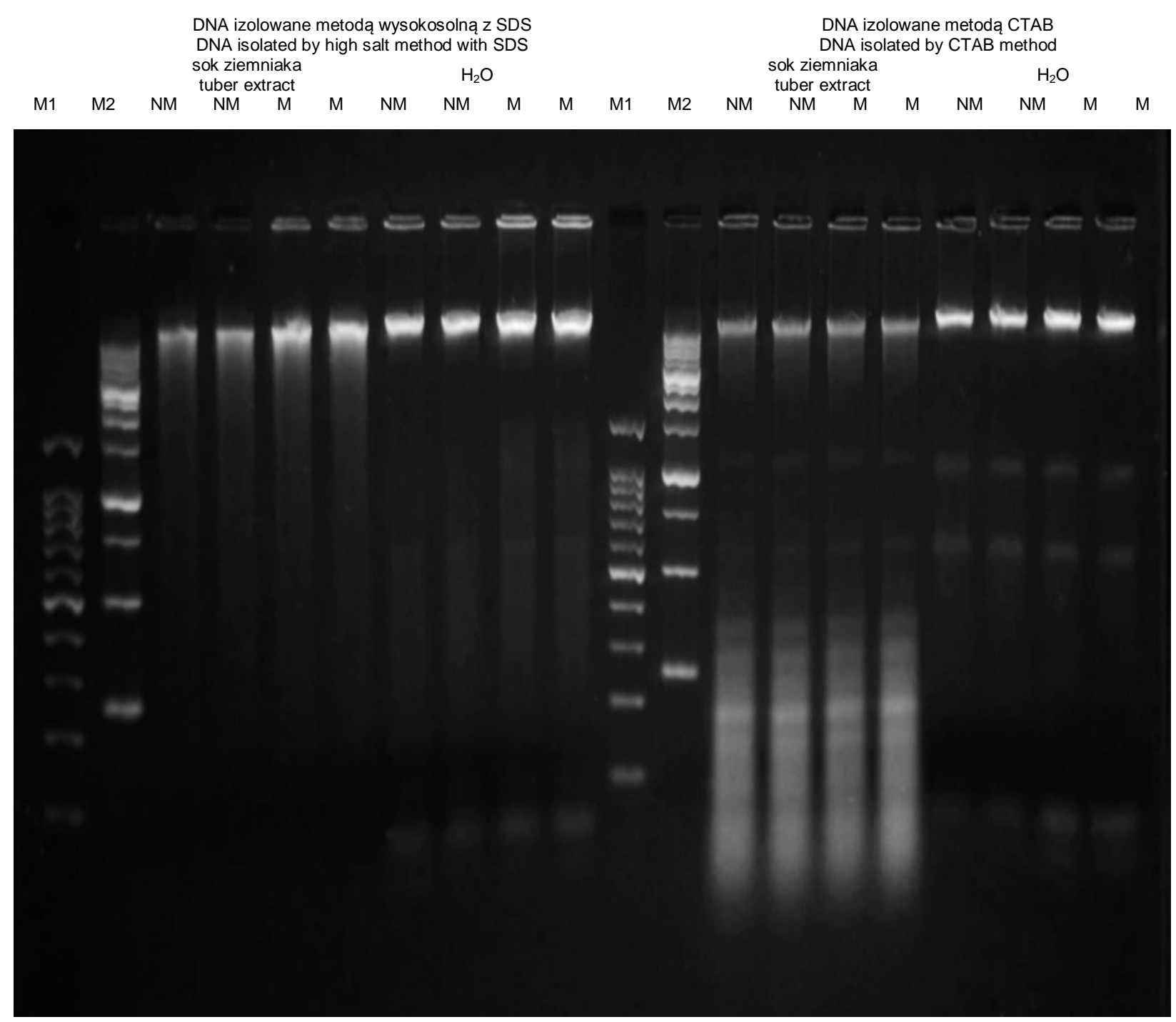

NM - DNA izolowane ze szczepu niemukoidalnego $\mathrm{Cms}$ - DNA isolated from low mucinous strain of $\mathrm{Cms}$

$\mathrm{M}$ - DNA izolowane ze szczepu mukoidalnego $\mathrm{Cms}$ - DNA isolated from mucinous strain of $\mathrm{Cms}$

M1 - Nova 100 bp DNA Ladder, Novazym

M2 - Nova $1 \mathrm{~kb}$ DNA Ladder, Novazym

SDS - dodecylosiarczan sodu - sodium lauryl (dodecyl) sulfate

Rys. 1. Jakość DNA izolowanego metodą wysokosolną i CTAB (cetyltrimethylammonium bromie - bromek cetylotrimetyloamoniowy) z dwóch zróżnicowanych mukoidalnie szczepów bakterii Clavibacter michiganensis subsp. sepedonicus (Cms)

Fig. 1. The quality of DNA isolated by CTAB (cetyltrimethylammonium bromie) and high salt method with mucinous differentiated Clavibacter michiganensis subsp. sepedonicus (Cms) bacteria

z różnych roślin. Metoda z użyciem wysokiego stężenia dodecylosiarczanu sodu (SDS) znalazła również szerokie zastosowanie $\mathrm{w}$ ekstrakcji materiału genetycznego $\mathrm{z}$ wielu różnych roślin, np.: tytoniu (Nicotiana), soi (Glycine max) i petunii (Petunia) (Dellaporta i wsp. 1983). Izolacja DNA tą metodą była możliwa nawet $\mathrm{z}$ tak trudnych tkanek, jak: igły świerkowe, liście ryżu czy wodorostów (Guillemaut i Maréchal-Drouard 1992; Csaikl i wsp. 1998; Wattier i wsp. 2000).

Opracowano również wiele gotowych zestawów do izolacji kwasów nukleinowych z tkanek roślinnych opartych na kolumienkach wirówkowych wypełnionych złożem. Jednak ich wykorzystanie w przypadku testowania dużej liczby prób nie zawsze jest możliwe ze względu na relatywnie wysokie koszty wykonania ekstrakcji.

Izolacja DNA z bulw ziemniaka jest szczególnie trudna ze względu na obecność w ekstraktach tkankowych polifenoli i polisacharydów, które hamują działanie polimerazy Taq DNA (Pastrik i Maiss 2000; Kotchoni i wsp. 2003). Dodatkowo podczas maceracji bulw komponenty fenolowe utleniają się i łączą z białkami oraz kwasami nukleinowymi tworząc trwałe kompleksy, obniżając w ten sposób jakość uzyskanego DNA, czyniąc go nieprzydatnym do amplifikacji techniką PCR (Porębski i wsp. 1997).

W prezentowanych badaniach porównywano dwie różne metody izolacji DNA, z których pierwsza (z dodatkiem 
CTAB) opierała się na usunięciu komponentów tkanek roślinnych oraz destrukcji błon i uwolnieniu kwasów nukleinowych z komórek bakterii. Ekstrakcję genomowego DNA przeprowadzano równocześnie metodą wysokosolną, w której zachodzi selektywne wytrącanie kwasów nukleinowych w obecności wysokich stężeń soli. Aby ocenić wpływ stopnia mukoidalności badanych bakterii na efektywność izolacji DNA, do badań wykorzystano dwa skrajnie zróżnicowane mukoidalnie szczepy $C m s$ w zawiesinach o stężeniu od 100 do 10 mln jednostek tworzących kolonie w mililitrze (jtk/ml). Największą ilość DNA otrzymano przez izolację metodą CTAB z bakterii Cms o wysokiej mukoidalności zawieszonych w soku ziemniaka. Nieco mniejszą wydajność uzyskano przy izolacji $\mathrm{z}$ bakterii zawieszonych $\mathrm{w}$ soku, ale charakteryzujących się niższą śluzowatością. W porównaniu $\mathrm{z}$ metodą wysokosolną, izolacja z CTAB pozwoliła uzyskać ponad trzykrotnie większą ilość DNA dla bakterii zawieszonych $\mathrm{W}$ soku ziemniaka, niezależnie od stopnia mukoidalności badanych szczepów. W przypadku zawiesin bakteryjnych $\mathrm{w}$ pozostałych mediach (bufor fosforanowy z NaCl oraz sterylna woda) wydajność izolacji DNA tą metodą była zdecydowanie niższa od metody CTAB, która utrzymywała się na jednakowym poziomie 0,023 $0,030 \mathrm{ug} / \mu 1$. Jedynie w przypadku izolacji z bakterii silnie mukoidalnych zawieszonych w wodzie metoda wysokosolna wykazała większą wydajność od metody z użyciem CTAB (tab. 3).

Jakość uzyskanych preparatów DNA oceniano na podstawie rozdziałów elektroforetycznych w żelu agarozowym (rys. 1). Preparaty izolowane $\mathrm{z}$ bakterii zawieszonych w wodzie wykazywały podobny stopień czystości i degradacji niezależnie od zastosowanej metody izolacji. Największy stopień degradacji i dużą ilość fragmentów o wielkości poniżej 500 pz obserwowano w preparatach DNA izolowanych $\mathrm{z}$ zawiesiny bakterii $\mathrm{W}$ soku ziemniaka metodą CTAB (rys. 1), ale wydajność tej metody była zdecydowanie wyższa $\mathrm{w}$ porównaniu $\mathrm{z}$ metodą wysokosolną (tab. 3).

Czułość testu PCR dla zawiesin bakteryjnych o stężeniu $10^{2}-10^{7} \mathrm{jtk} / \mathrm{ml}$ oceniano według warunków opisanych przez Pastrik (2000), zalecanych przez EPPO (European and Mediterranean Plant Protection Organization) do rutynowej kontroli fitosanitarnej pod kątem obecności bakterii Cms (OEPP/EPPO 2006). W przypadku preparatów DNA pochodzących $\mathrm{z}$ zawiesin $\mathrm{w}$ soku ziemniaka skuteczność identyfikacji dla obu metod była identyczna i zachodziła w pełnym zakresie rozcieńczeń $\left(10^{2}-10^{7} \mathrm{jtk} / \mathrm{ml}\right)$ dla szcze$\mathrm{pu}$ niskomukoidalnego i $\left(10^{3}-10^{7} \mathrm{jtk} / \mathrm{ml}\right)$ w przypadku szczepu o niskim stopniu śluzowatości. Test PCR z użyciem DNA pochodzącego $z$ komórek bakteryjnych zawieszonych w $1 \times$ PBS pozwolił wykryć $10^{3}$ jtk dla szczepu niskomukoidalnego zarówno przy izolacji $\mathrm{z}$ użyciem CTAB, jak i w warunkach wysokosolnych. Jedynie w przypadku DNA ze szczepu o niskiej śluzowatości zawieszonego w $1 \times$ PBS izolowanego techniką wysokosolną uzyskano czułość większą o jeden rząd wielkości w porównaniu z DNA izolowanym techniką CTAB. Czułość testu PCR $\mathrm{z}$ użyciem DNA izolowanego $\mathrm{z}$ bakterii zawieszonych $\mathrm{w}$ wodzie była taka sama dla obu technik i obu badanych szczepów wynosząc odpowiednio $10^{3} \mathrm{jtk} / \mathrm{ml}$ dla metody z użyciem CTAB oraz $10^{4} \mathrm{jtk} / \mathrm{ml}$ dla metody wysokosolnej.

Z danych literaturowych wynika, że wybór optymalnej metody izolacji DNA jest zależny od rodzaju rośliny i tkanki, która jest poddawana izolacji. Porównanie ośmiu metod izolacji DNA z surowych i przetworzonych bulw ziemniaka wykazało, że najlepszą wydajnością izolacji z surowych bulw charakteryzuje się metoda CTAB, a najlepszą jakość matrycy DNA uzyskano używając cząstek magnetycznych Kingfisher. Natomiast przy izolacji DNA z suszonych produktów ziemniaczanych najbardziej wydajny okazał się zestaw Wizard Magnetic DNA Purification for Food, Promega (Smith i wsp. 2005). Niezależnie od rodzaju badanej próby (bulwy ziemniaka, suszone plastry i płatki ziemniaczane, mąka ziemniaczana, skrobia i chipsy ziemniaczane) uzyskane DNA było dobrej jakości i mogło być wykorzystane do amplifikacji techniką PCR.

\section{Wnioski / Conclusions}

1. Zastosowana metoda izolacji DNA z komórek bakterii Cms wpływa na czułość testu PCR i jest zależna od medium, w jakim zawieszone są komórki bakteryjne.

2. Najlepszą jakość DNA i czułość testu PCR w wykrywaniu bakterii zawieszonych w soku ziemniaka uzyskano przy izolacji DNA techniką CTAB.

3. Mukoidalność badanych szczepów nie miała istotnego wpływu na efektywność izolacji DNA. Obniżenie czułości testu PCR występowało jedynie w przypadku szczepu silnie mukoidalnego, zawieszonego w soku ziemniaka, przy izolacji DNA techniką wysokosolną.

\section{Literatura / References}

Csaikl U.M., Bastian H., Brettschneider R., Gauch S., Meir A., Schauerte M., Scholz F., Sperisen C., Vornam B., Ziegenhagen B. 1998. Comparative analysis of different DNA extraction protocols: A fast, universal maxi-preparation of high quality plant DNA for genetic evaluation and phylogenetic studies. Plant Molecular Biology Reporter 16 (1): 69-86.

Dellaporta S.L., Wood J., Hicks J.B. 1983. A plant DNA mini-preparation: version 2. Plant Molecular Biology Reporter 1 (4): 19-21.

Doyle J.J., Doyle J.L. 1987. A rapid DNA isolation procedure for small quantities of fresh leaf tissue. Phytochemical Bulletin 19: $11-15$.

Doyle J.J., Doyle J.L. 1990. Isolation of plant DNA from fresh tissue. Focus 12: 13-15.

Edwards K., Johnstone C., Thompson C. 1991. A simple and rapid method for the preparation of plant genomic DNA for PCR analysis. Nucleic Acids Research 19, p. 1349.

Guillemaut P., Maréchal-Drouard L. 1992. Isolation of plant DNA: a fast, inexpensive, and reliable method. Plant Molecular Biology Reporter 10 (1): 60-65. 
John M.E. 1992. An efficient method for isolation of RNA and DNA from plants containing polyphenolics. Nucleic Acid Research 20 (9), p. 2381.

Kotchoni S.O., Gachomo E.W., Betiku E., Shonukan O.O. 2003. A home made kit for plasmid DNA mini preparation. African Journal of Biotechnology 2 (4): 88-90.

Mak Y.M., Ho K.K. 1992. An improved method for the isolation of chromosomal DNA from various bacteria and cyanobacteria. Nucleic Acids Research 20 (15): 4101-4102.

OEPP/EPPO 2006. Clavibacter michiganensis subsp. sepedonicus. Bulletin OEPP/EPPO Bulletin 36: 99-109.

Pastrik K.-H. 2000. Detection of Clavibacter michiganensis ssp. sepedonicus in potato tubers by multiplex PCR with coamplification of host DNA. European Journal of Plant Pathology 106: 155-165.

Pastrik K.-H., Maiss E. 2000. Detection of Ralstonia solanacearum in potato tubers by polymerase chain reaction. Journal of Phytopathology 148 (11-12): 619-626.

Porębski S., Bailey L.G., Baum B.R. 1997. Modification of a CTAB DNA extraction protocol for plants containing high polysaccharide and polyphenol components. Plant Molecular Biology Reporter 15 (1): 8-15.

Sharma A.D., Gill P.K., Singh P. 2002. DNA isolation from dry and fresh samples of polysaccharide-rich plants. Plant Molecular Biology Reporter 20 (4), p. 415.

Smith D.S., Maxwell P.W., De Boer S.H. 2005. Comparison of several methods for the extraction of DNA from potatoes and potatoderived products. Journal of Agricultural and Food Chemistry 53 (26): 9848-9859.

Wattier R.A., Prodohl P.A., Maggs C.A. 2000. DNA isolation protocol for red seaweed (Rhodophyta). Plant Molecular Biology Reporter 18 (3): 275-281.

Van Beckhoven J.R.C.M., Stead D.E., Van der Wolf J.M. 2002. Detection of Clavibacter michiganensis subsp. sepedonicus by AmpliDet RNA, a new technology based on real time monitoring of NASBA amplicons with a molecular Bacon. Journal of Applied Microbiology 93: 840-849. 